Creative Commons User License: CC BY-NC-ND

Abstracted by: EBSCOhost, Electronic Journals Service (EJS),

Google Scholar, Journal Seek, Scientific Commons,

Food and Agricultural Organization (FAO), CABI and Scopus

http://eoi.citefactor.org/10.11226/v23i4
Journal of Agricultural Extension

Vol. 23 (4) October, 2019

ISSN(e): 24086851; ISSN(Print); 1119944X

http://journal.aesonnigeria.org

http://www.ajol.info/index.php/iae

Email: editorinchief@aesonnigeria.org

\title{
Changing Agriculture Extension Models in Pacific Island Countries https://dx.doi.org/10.4314/jae.v23i4.4
}

\section{Chand, Atish}

Department of Crop Production, College of Agriculture, Fisheries and Forestry

Fiji National University.

E-mail: atish.chand@fnu.ac.fi +679 3479200

\section{Kumar, Salesh}

Department of Crop Production, College of Agriculture, Fisheries and Forestry

Fiji National University.

E-mail: salesh.kumar@fnu.ac.fj +679 3479200

\begin{abstract}
There has been a shift in extension service model in the Pacific Island Countries. Initially, extension service was largely provided by public sector but over the past decade there is an emergence of new extension service model. The extension services emerging are private owned or jointly managed by government and NGOs. Though the governments still play a larger role in extension service of the Pacific Islands countries, there are cases where some cooperatives and private organisations have resorted in providing their own extension service. In the neighbouring countries, Australia and New Zealand, a similar trend has resulted in extension service being privatized. This paper will provide insight into why and how far the transformation in extension service has occurred in the Pacific Island Countries.
\end{abstract}

Key words: Agribusiness, cooperatives, extension model, extension service, public extension

\section{Introduction}

Agricultural extension is of profound importance to the Pacific Island Countries (PICs). In the PICs, approximately $80 \%$ of the population is directly or indirectly dependent on the agriculture sector for their major source of livelihood, and for food and social security (Secretariat of the Pacific Community, 2015). The agriculture sector has relied on public extension service for development in PICs over the past few decades.

The market- driven reforms with a focus on agribusiness have altered the funding and delivery of agriculture and agricultural advisory services. A new paradigm in agricultural extension service is emerging through market development reforms in the Pacific Island countries (Pacific Community, 2018). This has resulted in major changes in the national agricultural extension and advisory service systems recently. Rabatsky \& Krause (2017), reported that agricultural extension services in some developed countries have been privatised and depends on private agribusinesses and agricultural agencies to provide service. In the United States, the extension service has been privatized (Adejo, Okwu, \& Ibrahim, 2012). The New Zealand extension service operates under user pay commercial criteria, while in England and Wales agricultural extension service is based on partial cost recovery basis whereby the user pays percent of the extension costs (Adejo, et al., 2012). It has also been 
Creative Commons User License: CC BY-NC-ND

Abstracted by: EBSCOhost, Electronic Journals Service (EJS), Google Scholar, Journal Seek, Scientific Commons,

Food and Agricultural Organization (FAO), CABI and Scopus
Journal of Agricultural Extension

Vol. 23 (4) October, 2019

ISSN(e): 24086851; ISSN(Print); 1119944X

http://journal.aesonnigeria.org

http://www.ajol.info/index.php/iae

Email: editorinchief@aesonnigeria.org

noted in Australia that the government has ceased funding agricultural extension and extension was privatised to the consultancy organisations (Reichelt, King, Ayre, \& Nettle, 2016).

In PICs, though the extension service is not completely privatised but can be noted for some agribusinesses and agriculture industry providing its own agricultural extension service. Non-Government Organisations (NGOs) and farmer organisations is also evolving in a similar role (SPC, 2015) to meet the extension service requirements. Despite this emerging trend, the public sector still remains the largest extension provider in PICs.

While limited agribusiness has privatized its agricultural extension in the past, recent emergence of private extension by the emerging agribusiness is noted. Though there is little documentation on the agricultural extension service model in PICs, the transition of agricultural extension model is an interesting shift. This paper documented the transition of agricultural extension services in the PICs. It detailed the emerging model and analysed the reasons for this transition. It also reviewed previous reports on the transition in agricultural extension model and cases study of privatisation of agricultural extension models in PICs.

\section{Background of Agriculture Extension in the South Pacific}

The agriculture extension service began after World War II to increase productivity to feed the underfed in the different developing countries In 1960s, agricultural extension was added to research or as department within the Ministry of Agriculture in the Pacific Island countries to transfer technology on export commodities. The SPC (2015), identifies the development of agricultural extension in the South Pacific in three phases namely;

Phase 1 (1950 -1960) - extension system was established within Ministry of Agriculture and commodity-oriented.

Phase 2 (1970 - 1980) - there was agricultural diversification, more graduates in agriculture extension were available and there was a strong donor push (World Bank, AusAid, NZAID).

Phase 3 (1990 - 2000s) - major focus shifted to a bottom-up approach. The extension service was decentralized, linkages between research and extension were strengthened, and privatization of extension service was noted amongst established agribusinesses.

In Fiji, the agricultural extension was introduced by the British Sugar Company and after independence and later was incorporated in the government policies (Global Forum for Rural Advisory Service, 2011). Traditionally in Fiji, the Ministry of Agriculture was the major agricultural extension provider for crop and livestock with exception of sugarcane which is served by Fiji Sugar Corporation. The government led agricultural extension has adopted a system of specialization and zoning whereby land surveys were done to determine the suitability of crops in an area and intensive extension programme drawn. Apart from the Ministry of Agriculture, Fiji, there have been upcoming NGO's and private sector playing a role in providing agricultural extension in Fiji. 
Creative Commons User License: CC BY-NC-ND

Abstracted by: EBSCOhost, Electronic Journals Service (EJS), Google Scholar, Journal Seek, Scientific Commons,

Food and Agricultural Organization (FAO), CABI and Scopus
Journal of Agricultural Extension

Vol. 23 (4) October, 2019

ISSN(e): 24086851; ISSN(Print); 1119944X

http://journal.aesonnigeria.org

http://www.ajol.info/index.php/jae

Email: editorinchief@aesonnigeria.org

A similar trend has been noted in Vanuatu. The Ministry of Agriculture, Quarantine, Fisheries and Forestry is the major provider of the agricultural extension service but later the non-state organisations evolved to provide extension concerned with specialist crops (Bird, 2017). Initially, in the PICs mostly dominated with subsistence agriculture, government provided extension service. With the shift of agriculture towards semi-commercialized and commercialized operations, privatised extension service evolved to meet the growing extension demand for the agriculture industry.

\section{Transition of Public Agricultural Extension Service}

In the PICs, public agriculture extension service is the most common means of providing agricultural extension service to farmers. An agricultural extension service integrated with other departments lacks the capacity to efficiently carry out agricultural extension activities. This public agriculture extension service largely relies on the central government to provide the agricultural extension service to farmers. This created a lot of pressure on the governments to meet the growing agricultural extension needs of the farmers. The pressure resulted in agricultural extension and advisory service becoming a separate agricultural extension department within the Ministry of Agriculture as noted in Samoa and Fiji in Figure 1 and 2 respectively.

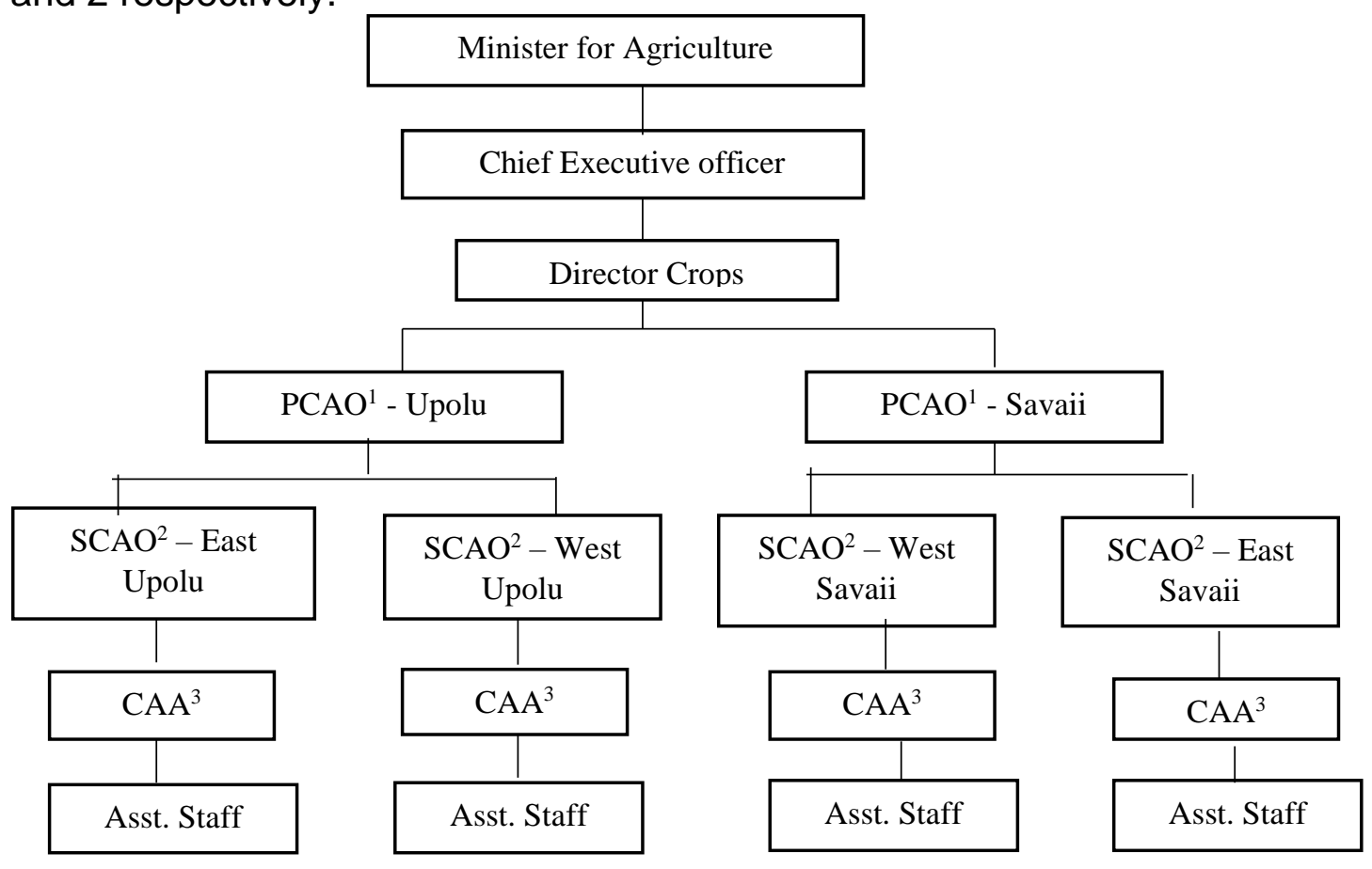

Figure 1: Organisational structure of the MAFs agriculture advisory service, Samoa (Adopted from Ministry of Agriculture and Fisheries, Samoa, 2019)

*Note: 1. Principal Crop Advisory Officer. 2. Senior Crop Advisory Officer 3. Crop Advisory Assistant. 


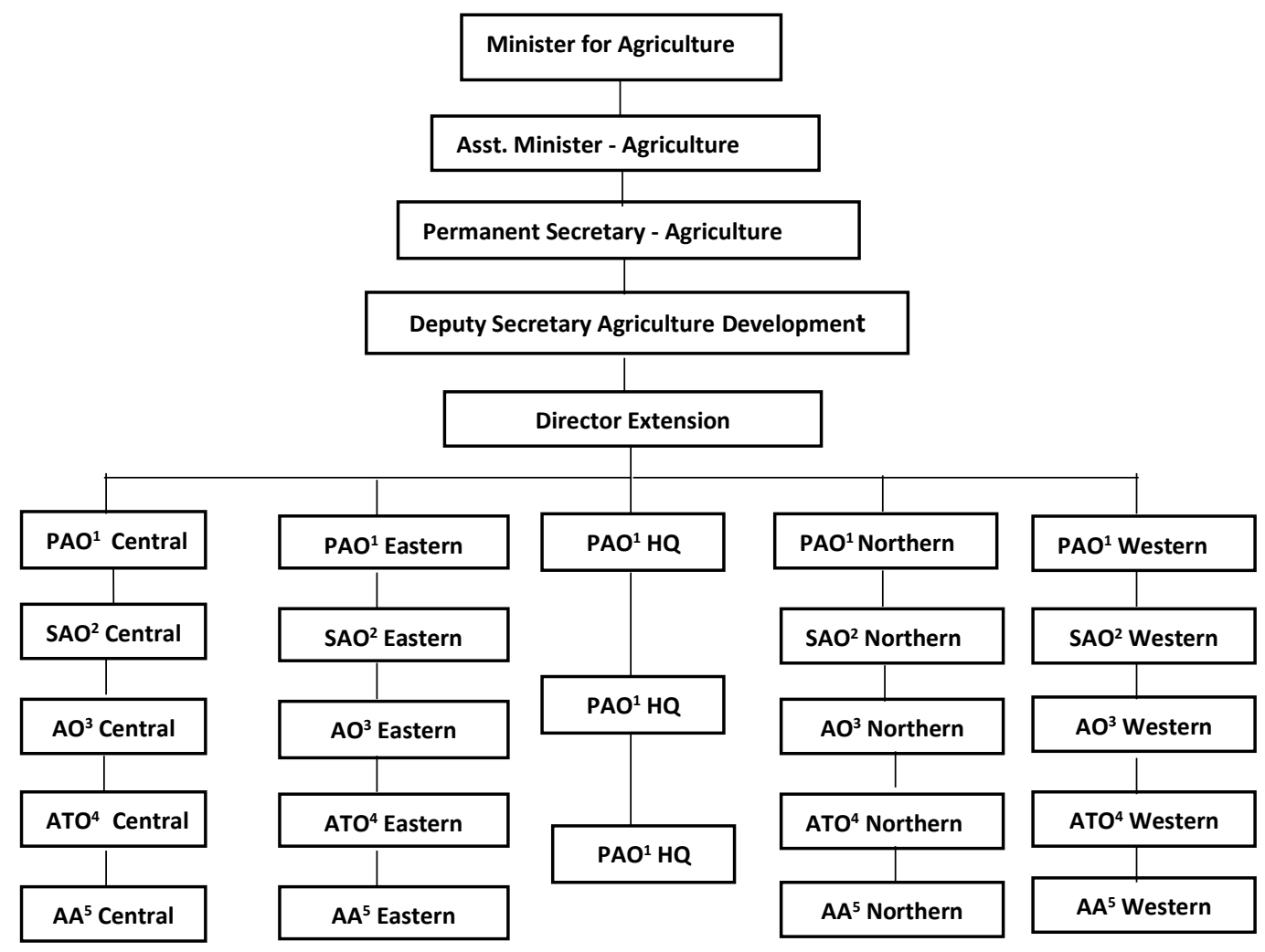

Figure 2: MOA - Organisational structure of the MOA's extension department, Fiji (Adapted from Sovalawa, 2018)

*Note: 1. Principal Agriculture Officer. 2. Senior Agriculture Officer. 3. Agriculture Officer. 4. Agriculture Technical Officer. 4. Agriculture Assistant. 5. Agriculture Assistant

The PIC governments also gave low priority to public agricultural extension, resulting in limited budget and stall allocation (Crowley, Karalus, Foo, \& Tasman, 2003; University of the Sunshine Coast, 2015). Generally, there is a weak linkage between the national agricultural research and extension. This is one of the difficult institutional problems faced by agriculture ministries (Adesoji \& Tunde, 2012; Altaye, 2012).

Apart from this, poor governance mechanism of agriculture extension departments has also resulted in public agricultural extension service failure (Dhital, 2017). Moreover, the lack of human capital in terms of staffing and skilled staff is persisting constraint. In 2007, public agricultural extension review in Vanuatu identified that staff do not complete their workload and lack adequate skills contributing to poor public agricultural extension service (Bird, 2017; University of the Sunshine Coast, 2015). In Samoa, lack of adequate qualified staff has also constrained the public agricultural extension service to meet the demand of the farmers. 
Creative Commons User License: CC BY-NC-ND

Abstracted by: EBSCOhost, Electronic Journals Service (EJS), Google Scholar, Journal Seek, Scientific Commons,

Food and Agricultural Organization (FAO), CABI and Scopus
Journal of Agricultural Extension

Vol. 23 (4) October, 2019

ISSN(e): 24086851; ISSN(Print); 1119944X

http://journal.aesonnigeria.org

http://www.ajol.info/index.php/iae

Email: editorinchief@aesonnigeria.org

In Fiji only 34 percent (Table 1) of the farmers were visited by extension officers. This indicates that the lack of capacity to meet the agricultural extension demand of farmers by the public agricultural extension sector.

\begin{tabular}{|c|c|}
\hline Type & $\begin{array}{l}\% \text { of farmers } \\
\text { reached }\end{array}$ \\
\hline Visited by an agriculture officer & 34 \\
\hline Visited an agricultural office & 26 \\
\hline Attended a field day & 9 \\
\hline
\end{tabular}

Burdened with of these constraints, agriculture extension service in the PICs has been evolving into new models which can meet the needs of the farmers. Though public agricultural extension continues to play a major role in the PICs there are other forms of agricultural extension service emerging.

\section{Privatisation of Agricultural Extension Service}

In the PICs, extension has not been completely privatized as public extension service still provides wider extension service to its individual clients. Apart from extension service provided by the public sector, there has been major contribution by donor agencies in agriculture and extension development (Secretariat of the Pacific Community, 2015). These donor agencies empower civil societies to improve policies, capacity building in human resources and improving institutional structure in the rural communities. Global Forum Rural Advisory Services (GFRAS), Pacific Island Rural Advisory Service (PIRAS), Pacific Island Farmers Network (PIFON), and Secretariat of the South Pacific (SPC) are some of the major NGOs/civil organisations working in the PICs to improve the agricultural extension service.

The PIC governments are also vesting partnership to farmer, NGO and private agribusiness enterprises to improve the extension service. This effort has seen private agricultural extension service being provided by the agribusiness companies, cooperative and NGOs. Though there may be some dispute regarding the authenticity with this partnership arrangement but this appears to meet the growing demand for food and sustenance of natural resources.

\section{Privatised Extension in PICs}

Fiji The privatization of extension in Fiji started with British Sugar Company after independence. Later, Fiji Sugar Cooperation, this institution continues to provide its own extension service in Fiji. Apart from this institution, recently it has been noted that there are other agribusiness organisations coming up with their own extension service.

Recently, it has been noted that apart from traditional public extension model, there has been evolving of new extension models. The extension model stresses farmer 
organisations and cooperatives to provide its own extension. In Fiji, Koronivia Farmer Cooperative consisting of ten farmers was formed to get a tractor from the government as a grant under Farming Assistance Scheme (FAS). According to Prasad (2018), the MOA is not the only provider of the agricultural extension advise but the member farmers also assist each other by rendering advise as cooperative when there is a need. Fiji Crop and Livestock Council (FCLC), comprising of associations consisting of twelve commodities. Through this associations, the farmers are excessing agriculture information through mobile. To add, Nature's Way Cooperative has developed a defined market for its products and providing its extension support to promote export.

Papua New Guinea: The agricultural extension service in Papua New Guinea has also been dominated by the public extension sector but due to ineffective provided some of the organisations have chosen to provide their own extension service. The Papua New Guinea Development Bank (PNGDB) dismayed by the public service extension provided to its smallholder farmers decided to provide its own extension service to its farmers. For example, PNGDB is developing small holder cocoa blocks by providing its own technical service and the cost is met by deductions from farmer's bank loans.

A similar situation has been noted with Ok Tedi Mining Ltd, which resorted to providing own extension service since the public extension was inefficient in growing food for the miners. These extension services from the company was provided to the nearby villages which provided a secure supply of fresh vegetables to the minors working in the company.

\section{Emerging Extension Models in the Pacific}

The traditional extension service model had the government and the NGO's providing service to farmers. Figure 4 shows traditional and emerging agricultural extension model. The traditional model includes government and NGOs providing agricultural extension. These mostly include training and visit approach. The emerging agriculture extension model has evolved into government and NGOs working with both individual farmers and farmer organisations to provide extension service to farmers. Increase in farmer organisations has been noted to provide major extension service in PICs (Global Forum for Rural Advisory Service, 2011). Apart from farmer organisations, and public extension service, increase in private agribusiness firms is noted to be involved in providing its own agricultural extension. 
Creative Commons User License: CC BY-NC-ND

Abstracted by: EBSCOhost, Electronic Journals Service (EJS),

Google Scholar, Journal Seek, Scientific Commons,

Food and Agricultural Organization (FAO), CABI and Scopus
Journal of Agricultural Extension

Vol. 23 (4) October, 2019

ISSN(e): 24086851; ISSN(Print); 1119944X

http://journal.aesonnigeria.org

http://www.ajol.info/index.php/iae

Email: editorinchief@aesonnigeria.org

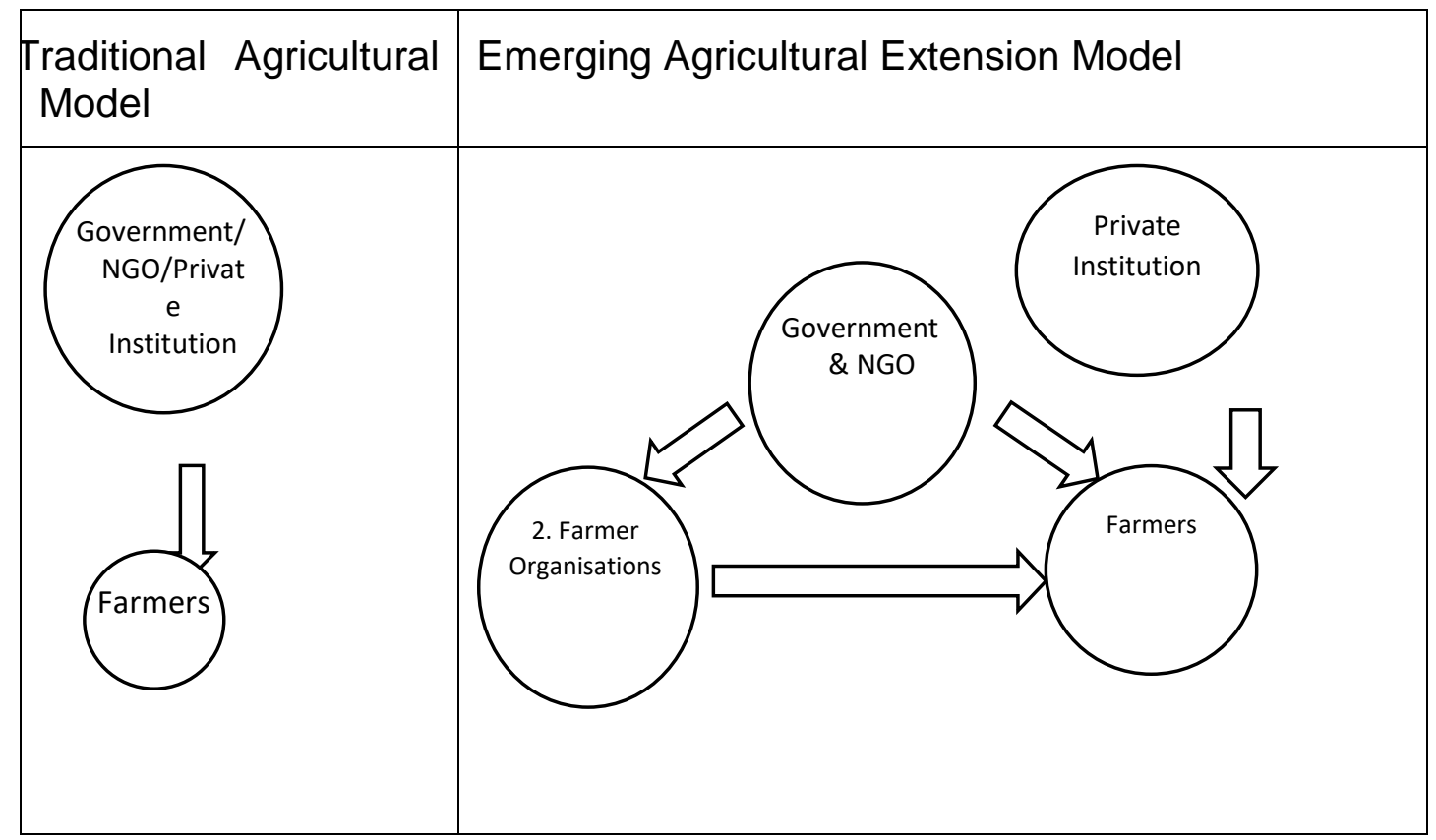

Figure 4: Traditional and emerging agriculture model

Initially, extension was largely provided by the government of the country. Agriculture extension department is a major arm of all agriculture ministries which traditionally provided the extension services to farmers. This extension service was conducted using face to face, group or mass contact methods. This was a similar scenario in the developed countries but there has been a shift in extension model from public to private sector. Evolving of privatized extension service was seen as an effective means of delivering extension service to farmers in developed countries. A similar trend has started in the developing PIC's whereby shift in agricultural extension service have been noted. The major motivation for this change has been attributed to the reduction in public spending of North and South countries.

In PICs, though it is not a complete transition from public to private sector but some shift towards private sector participation in agricultural extension service can be recognized. The privatisation of agricultural extension service can be an effective way of commercializing agriculture and relieving financial burden from the government. This will enable government to focus more on policies, human resource development, infrastructure and institutional development. Privatisation of agricultural extension service also has potential to attract best graduates of a country by offering more attractive conditions for private agencies to operate. On the contrary, privatisation of agricultural extension services can lead to increased social costs and environmental hazards. As seen in the PICs, private agricultural extension services are more conveniently afforded by agribusiness firms. Therefore, poor farmers will not be able to afford for private agricultural extension service.

A solution to these issues in PICs can be the strengthening cooperatives. As seen in Fiji, cooperative organisations can be a better solution to provide affordable private agricultural extension to farmers. Therefore, more capacity building can enable 
Creative Commons User License: CC BY-NC-ND

Abstracted by: EBSCOhost, Electronic Journals Service (EJS), Google Scholar, Journal Seek, Scientific Commons,

Food and Agricultural Organization (FAO), CABI and Scopus
Journal of Agricultural Extension

Vol. 23 (4) October, 2019

ISSN(e): 24086851; ISSN(Print); 1119944X

http://journal.aesonnigeria.org

http://www.ajol.info/index.php/iae

Email: editorinchief@aesonnigeria.org

cooperatives to provide affordable agricultural extension service to farmers. Strength of cooperative in providing agricultural extension service is quite eminent in India and Japan. The Central Union of Agricultural Cooperatives of Japan, a national apex agricultural cooperatives, operates a full-fledged department of farm guidance while in India the National Cooperative Union of India [NCUI], implements world's largest cooperative education and training programme for 550,000 cooperatives with a membership of nearly 225 million (Zamagni, 2012).

Finally, the evaluation and impacts of the privatizing extension service in the Pacific have not been done but there are positive and adverse impacts of this transition. This area can be studied to understand the consequence of privatising agricultural extension service.

\section{Conclusion and Recommendations}

In the PICs, the evolution of public agricultural extension service has been evident. There is partial shift of public agricultural extension to farmer alliances/organisation and private institutions. The public sector remains the major extension service provider in the PICs, but reports and studies indicate that the government funding for extension is reducing and that the governments are not able to meet the growing demand for the agricultural extension services. This has resulted in emergence of civil societies and agribusinesses to work with the government and stakeholders in trying to improve the extension service. These changes suggest that there is a shift in traditional extension model and a new extension model is emerging in the PICs. Therefore, it is strongly suggested that PIC governments should strengthen and the cooperative institutions and develop policies to incentivise agribusiness led extension.

\section{References:}

Adejo, P., Okwu, O., \& Ibrahim, M. (2012). Challenges and prospects of privatization of agricultural extension service delivery in Nigeria. Journal of agricultural extension and rural development, 4(3), 63-68.

Adesoji, S., \& Tunde, A. (2012). Evaluation of the linkage system of research-extensionfarmers in Oyo State, Nigeria: Lesson for Agricultural Extension administrators. Journal of Agricultural Extension and Rural Development, 4(20), 561-568.

Altaye, S. (2012). Analysis of research-Extension-Farmer Linkage in Fingermillet technology development in delivery in Mecha district of Amhara region, Ethiopia. Journal of Agril. Eco. and Dev, 1(6), 121-129.

Bird, A. (2017). Local Learnings from Local Voices: Exploring rural ni-Vanuatu perspectives of agricultural education and extension services in Santo, Vanuatu.

Dhital, P. R. (2017). Agricultural Extension in Nepal: Experiences and Issues. 
Creative Commons User License: CC BY-NC-ND

Abstracted by: EBSCOhost, Electronic Journals Service (EJS), Google Scholar, Journal Seek, Scientific Commons,

Food and Agricultural Organization (FAO), CABI and Scopus
Journal of Agricultural Extension

Vol. 23 (4) October, 2019

ISSN(e): 24086851; ISSN(Print); 1119944X

http://journal.aesonnigeria.org

http://www.ajol.info/index.php/iae

Email: editorinchief@aesonnigeria.org

Global Forum for Rural Advisory Service. (2011). Related resources Retrieved 15/08/2018, 2018, from https://www.g-fras.org/en/world-wide-extension-study/84-world-wideextension-study/oceania/338-fiji.html\#title-related-resources

Ministry of Agriculture. (2016). Livestock sector strategy report. Suva: Ministry of Agricuture.

Pacific Community. (2018). The Pacific Islands extension strategy; Strategic priorities in agricultural extension and rural advisory services in the Pacific region (2018 - 2019)

Prasad, J. (2018). [Koronivia Farmers Cooperative].

Rabatsky, B., \& Krause, M. (2017). Private sector provision of rural advisory services: gfras.

Reichelt, N., King, B., Ayre, M., \& Nettle, R. (2016). Enrolling advisers in governing privatised agricultural extension in Australia: challenges for the innovation system. Paper presented at the 12th European International Farming Systems Association (IFSA) Symposium, Social and technological transformation of farming systems: Diverging and converging pathways, 12-15 July 2016, Harper Adams University, Newport, Shropshire, UK.

Secretariat of the Pacific Community. (2015). The Pacific Islands extension strategy: Strategic priorities in agricultural extension and rural advisory service delivery 2015 2020. New Caledonia: SPC.

SPC. (2015). Global review of extension approches and models Land Resource Division Pacific Community.

University of the Sunshine Coast. (2015). Pacific examples of good extension practice. Queensland: SPC.

Zamagni, V. N. (2012). Interpreting the roles and economic importance of cooperative enterprises in a historical perspective. Journal of Entrepreneurial and Organizational Diversity, 1(1), 21-36. 